Ettore Recchi, Sciences Po Paris

\title{
The Engine of 'Europeanness'? \\ Free Movement, Social Transnationalism and European \\ Identification
}

\section{The Spatial Bases of European Identification}

One of the things that Brexit proved is that Europe's root problem is Europeans' selfidentification. It is not by chance that the only (or the first?) country that has seceded from the EU is the UK. For decades, Britons have scored on top of Eurobarometer as the EU citizens least willing to call themselves 'European'. Collective identification matters. A poor sense of Europeanness means no solidarity with other Europeans. No solidarity translates into little public support to European institutions when they endeavour to impose redistributive policies or to pool member states' resources. An appeal to German taxpayers to pay off the Greeks' debts cannot leverage - as happened after reunification of the two Germanies - a strong bond between the two populations. There is no financial alchemy or constitutional engineering able to remedy this basic flaw of European integration.

What can make Europeans feel 'European'? What can bind them to a political-territorial community that was created top-down and only relatively recently? Historically, when nation states took up the challenge of nation-building, they used the instruments of compulsory conscription, mass education (in particular the teaching of history and geography), explicit propaganda (especially in times of crisis), and 'banal nationalism' expressed through widespread symbols and implicit fictions. ${ }^{1}$ Today, compulsory military service has been discontinued by almost all the EU member states (with a few after-thoughts), so that implementing it on a continental scale would hardly be feasible. As regards education, a history of Europe purged of nationalistic biases was proposed by scholars from different countries. But limited use has been made of these textbooks, which tend to be hostage of national controversies about key historical characters and

\footnotetext{
${ }^{1}$ M Billig, Banal Nationalism (London, Sage, 1995).
} 
events. ${ }^{2}$ As for propaganda, the European Commission has promoted a wide range of media campaigns, especially on the occasion of major changes such as introduction of the euro. Less episodically, it is this propagandistic purpose that lies behind many of EU's cultural policies such as the designation of the 'European Years' or a European capital of culture. ${ }^{3}$ Last but not least, there is 'banal Europeanism' hinged on an array of different tools. Some of them have a deliberate identitarian connotation: the European flag, the European anthem, Europe Day (on the 9th of May, anniversary of the Schuman Declaration). Others were put in place for different purposes: for instance, the common currency or free movement rights. But have these policies had any effects on bolstering a European identity?

In this paper, I concentrate on free movement, arguing that it has a very strong potential of fostering a sense of 'Europeanness'. The starting point of my argument rests on psychogeographical knowledge, according to which humans are territorial beings. The localization of life-worlds nurtures a sense of spatial confidence that tends to turn into spatial attachment. ${ }^{4}$ Permanence in a physical context breeds adaptation, familiarity, and eventually an attachment to it. This, in turn, substantiates the taken-for-granted nature of its institutions, thus contributing to the legitimacy of on-going collective arrangements, including political ones. ${ }^{5}$ In other words, people's inclination to be attached to the places where they spend or have spent their life - the places that constitute an individual's 'space-set' ${ }^{6}$ - fits in with intentional activities of power-holders to demand legitimacy for the existing political order inasmuch as such order coincides geographically with the subjects' (or citizens') space-set. Concretely, loyalty to a given country is higher if people have a first-hand experience of that country's territory (and especially of symbolically core places). One of the latent functions of conscription has always been to socialize youth

\footnotetext{
${ }^{2}$ S Immerfall, K Boehnke and D Baier, 'Identity' in S Immerfall and G Therborn (eds), Handbook of European Societies, 2nd edn (New York, Springer, 2010) 325, 345ff.

${ }^{3}$ M Sassatelli, 'Imagined Europe: The Shaping of a European Cultural Identity through EU Cultural Policy' (2002) 5 European Journal of Social Theory 435.

${ }^{4}$ YF Tuan, Space and Place: The Perspective of Experience (Minneapolis, University of Minnesota Press, 1977); RD Sack, Human Territoriality: Its Theory and History (Cambridge, Cambridge University Press, 1986); J Lévy, Lespace légitime. Sur la dimension géographique de la fonction politique (Paris, Presses de la FNSP, 1994); A Moles and E Rohmer, Psychosociologie de l'espace (Paris, L'Harmattan, 1998).

${ }^{5} \mathrm{H}$ Popitz, Phenomena of Power. Authority, Domination, and Violence (New York, Columbia University Press, 2017 [1986]) chapter 2.

${ }^{6}$ E Recchi, 'Space, Mobility and Legitimacy' in WR Thompson (ed), Oxford Research Encyclopedia of Politics (Oxford, Oxford University Press, 2016); E Recchi and T Kuhn, 'Europeans' Space-Sets and the Political Legitimacy of the EU' in N Kauppi (ed), A Political Sociology of Transnational Europe (Colchester, ECPR Press, 2013).
} 
to different regions of 'their' nation. Internal migration yields a similar effect. Although some may fear it can erode community bonds ${ }^{7}$, in fact it spreads out the sense of belonging to a larger spatial unit - the nation. The US and Chinese instances - where internal migration is robust as well as national identification - are cases in point.

According to this logic, in contemporary Europe the free movement regime should facilitate the same outcome on a transnational scale. Albeit with different underlying (and not entirely explicit) theoretical premises, indeed such insight sits well with Karl Deutsch's 'transactionalist thesis' on European integration. The thesis is an upshot of Deutsch's earlier theory of nationalism. ${ }^{8}$ In his view, nation-building comes about mainly through the construction of 'infrastructures' which facilitate economic and social exchanges within territorial boundaries. Infrastructures create 'societies', while communication and culture create 'communities'. But the latter cannot exist without the former. The sense of belonging to a nation grows out of the intensification of social relations within it. In a nation-centered world, co-nationals interact with each other more than they do with people external to the nation, thereby strengthening their sense of solidarity and common destiny. Once people start to communicate regularly and cluster across national borders, however, their spatially-bounded connections trigger a reconfiguration of collective attachments. Deutsch accordingly notes that 'boundaries are not just lines on a map [...] what really makes a boundary is a sharp drop in the frequency of some relevant transaction flow'. ${ }^{9}$ As in the case of incipient nations, the expansion of economic, social and cultural exchanges across the boundaries of pre-existing polities is expected to lead to the formation of 'security communities' - one of which was the newborn European Economic Community, which Deutsch held could progressively endow itself with a collective identity through increased transnational interactions. ${ }^{10}$

\section{Assessing the 'Free Movement' Effect}

\footnotetext{
${ }^{7}$ RD Putman, Bowling Alone: The Collapse and Revival of American Community (New York, Simon and Schuster, 2000).

${ }^{8}$ KW Deutsch, Nationalism and Social Communication: An Inquiry into the Foundations of Nationality (Cambridge (MA), MIT Press, 1953).

${ }^{9}$ KW Deutsch, Nationalism and Its Alternatives (New York, Knopf, 1969$) 97$.

${ }^{10} \mathrm{KW}$ Deutsch et al, Political Community and the North Atlantic Area: International Organization in the Light of Historical Experience (Princeton, Princeton University Press, 1957).
} 
In the previous section, I sketched out two converging but theoretically distinct hypotheses. The first one drew on psycho-geographical tenets to claim that individuals with personal experiences of life in different European countries are expected to be more prone to see themselves as 'European'. EU citizens who have moved to another member state under the aegis of the free movement regime belong to such possibly more proEurope population. To test the hypothesis, I will use original survey data collected in 2004 and 2010 on intra-EU migrants and pool them with Eurobarometer data on the general, immobile population of nationals of each EU country. Statistical analysis, in the form of logistic regressions, will control whether - ceteris paribus - 'EU movers' are more likely to feel attached to Europe than 'EU stayers'. ${ }^{11}$ The second hypothesis drew on Karl Deutsch's argument of the effect of cross-border activities on individual outlooks: the more people engage in transnational practices, the more they are likely to adopt a supranational identification. To test the hypothesis, I will rely on data from Eurobarometer 73 of 2010 that record a list of ten possible individual cross-border behaviours (from watching foreign tv to travelling abroad: see below). Multilevel logistic regression will control whether the more people act transnationally, the more they feel attached to Europe.

To begin with, I will present the analyses which compare the sense of belonging to Europe between movers and stayers. A key point to bear in mind is that EU movers form a small fraction of Europeans. EU citizens resident in another member state hover around 3 per cent of the total population. ${ }^{12}$ This makes it impracticable to study their characteristics, behaviours, and attitudes using data from sample surveys conducted with random criteria on the entire population: even in large-scale surveys, the absolute number of sampled cases would be rather modest. A solution is to combine data from population surveys with data from ad hoc surveys on migrants that deal with the same phenomena using the same indicators. This is the strategy adopted here, by merging Eurobarometer data with data from the European Internal Movers' Social Survey (EIMSS) and Moveact surveys, which

\footnotetext{
${ }^{11}$ A methodological caveat is in order: cross-sectional survey data (that is, collected at one particular time) cannot be used to establish conclusively whether this possible difference is due directly to the experience of mobility or to other factors that preceded it. Only longitudinal information collected before and after migration would settle the question. However, there are theoretical reasons (illustrated in the previous section) that do justify the expectation that the experience of cross-border mobility fosters supranational identifications rather than the other way around.

${ }^{12}$ E Recchi, Mobile Europe. The Theory and Practice of Free Movement in the EU (Basingstoke, Palgrave Macmillan, 2015) 52ff.
} 
were designed to make this operation possible. ${ }^{13}$ More specifically, I constructed a first joint matrix relative to 2004 with data from Eurobarometer 62 and the EIMSS survey on German, British, French, Spanish and Italian nationals. The second matrix has 2010-2011 as its temporal reference, and pools data from Eurobarometer 73 of 2010 with data from the 2011 Moveact survey on citizens of German, British, Polish and Romanian nationality. ${ }^{14}$ It is thus possible to compare - amongst other things - the sense of identification with Europe of the stayers and movers of different countries at two distant moments of time.

Figure 1. Feeling European: EU movers and stayers who declare themselves to be 'very attached' to Europe (2004 and 2010-11)

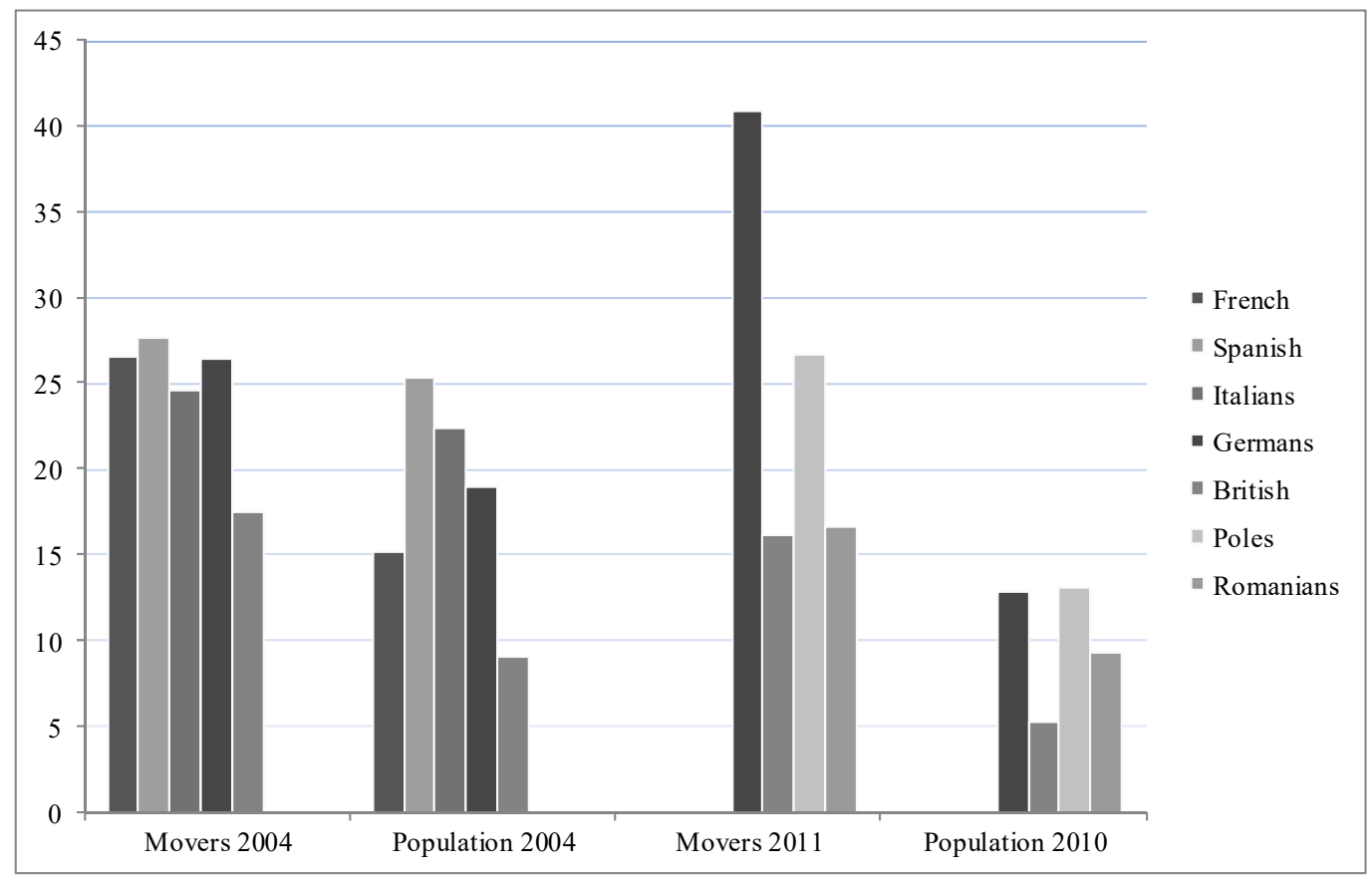

${ }^{13}$ Recchi (note 12) 155-157.

${ }^{14}$ None of the 2011 Eurobarometers contain the dependent variable common to all the other surveys: the question on 'attachment to Europe'. I therefore had to rely on the survey closest in time able to ensure full comparability: the Eurobarometer 73.3 of March-April 2010. Moreover, to be precise, in the latter survey the response item was not phrased as 'Europe' but rather as the 'European Union'. This is an unfortunate change which must be factored in, but - also in consideration of the question structure, which is for the rest unaltered - I assume it to be an analogously trustworthy measurement of the European component of identification. 
Sources: 2004: Eurobarometer 62 and EIMSS (N=10,728); 2011: Eurobarometer 73 and Moveact $(\mathrm{N}=6,852)$.

Both surveys show that European citizens who feel 'very attached' to Europe are proportionally more numerous among those living in another member state than in the rest of the population (Figure 1). This is also the case within each nationality examined, independently of its level of identification with Europe. In absolute terms, in 2004, the Spanish respondents, both stayers and movers, accounted for the largest proportion of convinced Europeans. In 2010-11, across a different range of nationalities, the highest level of European identification was expressed by Germans among mobile citizens and Poles among non-mobile ones. Not surprisingly (especially ex post), in both 2004 and 2010-11, British respondents recorded the lowest levels of attachment to Europe. In the more recent survey, the percentage of Romanians who expressed a strong attachment to Europe was almost equally low (16.7 per cent among movers and 9.3 per cent among stayers). But there are no exceptions to the rule that attachment to Europe is more widespread among mobile citizens. Moreover, among the nationalities for which it makes sense to conduct intertemporal comparison - German and British - a decrease in the proportion of respondents strongly attached to Europe is apparent among stayers but not among movers. Indeed, in the sample of Germans resident abroad in 2011, 41 per cent of respondents were very attached to Europe.

Table 1. Determinants of attachment to Europe in 2004 and 2010-11: logit regressions ('very attached' vs. 'fairly, not very or not at all attached')

\begin{tabular}{|c|c|c|c|c|}
\hline & 2004 & & $2010-11$ & \\
\hline Intra-EU mobility & 1.734 & $* *$ & 3.857 & $* *$ \\
\hline \multicolumn{5}{|c|}{ Age (ref: $>60$ yrs old) } \\
\hline $15-30$ & .781 & * & .942 & \\
\hline $31-40$ & .804 & $*$ & .961 & \\
\hline
\end{tabular}




\begin{tabular}{|c|c|c|c|c|}
\hline $41-50$ & .905 & & .803 & \\
\hline $51-60$ & 1.112 & & .905 & \\
\hline Gender (=woman) & .732 & $* *$ & .827 & $*$ \\
\hline \multicolumn{5}{|l|}{ Education (ref: Low, up to 15) } \\
\hline Middle (up to 16-19) & 1.304 & $*$ & 1.105 & \\
\hline High (after 19) & 2.032 & $* *$ & 1.751 & $* *$ \\
\hline \multicolumn{5}{|l|}{ Social class (ref: EGP VII) } \\
\hline EGP I-II & 1.383 & $* *$ & 1.209 & \\
\hline EGP III & 1.167 & & .852 & \\
\hline EGP IV & 1.189 & & 1.127 & \\
\hline EGP V-VI & 1.042 & & .827 & \\
\hline \multicolumn{5}{|l|}{ Nationality (ref: German) } \\
\hline French & .918 & & - & \\
\hline British & .472 & $* *$ & .368 & $* *$ \\
\hline Spanish & 1.214 & $*$ & - & \\
\hline Italian & 1.060 & & - & \\
\hline Polish & - & & .698 & $* *$ \\
\hline Romanian & - & & .423 & $* *$ \\
\hline Local identification & 1.041 & & 1.259 & $*$ \\
\hline Regional identification & 3.324 & $* *$ & - & \\
\hline National identification & 2.182 & $* *$ & 2.691 & $* *$ \\
\hline
\end{tabular}

Sources: 2004: Eurobarometer 62 and EIMSS: $\mathrm{N}=9,254 ; \mathrm{df}=19$; chi-square $=3852.56$; Nagelkerke $\mathrm{R}^{2}=, 18$. 2010-11: Eurobarometer 73 and Moveact: $\mathrm{N}=6,344 ; \mathrm{df}=17$; chi-square $=1916.80$; Nagelkerke $\mathrm{R}^{2}=.17$. Note: $* \mathrm{p}<.05, * * \mathrm{p}<.01$. Coefficients are odds ratios.

Of course, this preliminary analysis yields only inconclusive findings, given that the difference between movers and stayers may also be due to the differing composition of the samples. To neutralize this possibility, I conducted multivariate analyses which 
control for the simultaneous effect of the main sociological factors that can influence the level of European identification. Table 1 presents the results of two logistic regression models of such factors on the dichotomous dependent variable described in Figure 6.1: that is, self-definition or otherwise as 'very attached to Europe'. ${ }^{15}$ The first model refers to the 2004 sample (consisting of the Eb62 and EIMSS data), the second to the 2010-11 sample (consisting of Eb73 and Moveact data). In both cases, experiencing intra-EU mobility is one of the strongest predictors of attachment to Europe. In 2011, in fact, assuming the overall combination of the reference modalities of the control variables introduced into the model, mobility is associated with four times higher odds of feeling 'very attached' to Europe, standing out as the single most powerful independent variable of the model. As to be expected, education - in particular, up to tertiary level (that is, after the age of 19) - tends to engender a greater sense of Europeanness as well. By contrast, upper class membership is significant in the first but not the second model. Likewise, whilst in the first model attachment to Europe was significantly lower among interviewees in the younger age groups, this is not the case in the 2010-11 surveys. Gender differences are in line with most of the literature: men are more inclined to describe themselves as European. ${ }^{16}$

Unfortunately, the two datasets do not contain data relative to values and political attitudes that might be important (for instance, self-placement on the right-left scale). ${ }^{17}$ But information regarding the other competing political-territorial identities is indeed available. Analysis reveals that strong regional and national identities - to which local ones were also added in 2011 - are associated with attachment to Europe. This may be

\footnotetext{
${ }^{15}$ Caution is needed when interpreting parameters of logistic regressions conducted on different samples, see: C Mood, 'Logistic Regression: Why We Cannot Do What We Think We Can Do, and What We Can Do About It' (2010) 26 European Sociological Review 67. As long as it cannot be assumed that unobserved heterogeneity is the same across such samples, effects cannot be compared properly. In this light, the two models examined here (and in following analyses of this chapter) must be read as two parallel takes on the issue rather than a way to gauge changes in the influence of only apparently comparable factors.

${ }^{16}$ B Nelson and J Guth, 'Exploring the Gender Gap: Women, Men and Public Attitudes toward European Integration' (2000) 1 European Union Politics 267; J Citrin and J Sides, 'More than Nationals: How Identity Choice Matters in the New Europe' in RK Herrmann, T Risse and MB Brewer (eds), Transnational Identities: Becoming European in the EU (Lanham, MD: Rowman \& Littlefield, 2004); T Risse, A Community of Europeans? Transnational Identities and Public Spheres (Ithaca, Cornell University Press, 2010).

${ }^{17}$ An emphasis on the pro-Europe impact of cross-border mobility and transnational behaviours should not blind us to socialization effects: a recent study on EU-oriented solidarity attests that these two types of antecedents tend to interact, see: I Ciornei and E Recchi, 'At the Source of European Solidarity: Assessing the Effects of Cross-border Practices and Political Attitudes' (2017) JCMS: Journal of Common Market Studies DOI: $10.1111 / \mathrm{jcms} .12507$.
} 
the substantive expression of a sensibility underlying the collective dimension of social life in its territorial variants. More prosaically, however, not to be excluded is the presence of a 'response set' which reduces the discriminatory capacity of these indicators. Finally, British origin is correlated negatively - and considerably so - with European identification in both surveys. It is especially negative in comparison with the reference category - German nationality - which is significantly associated with an attachment to Europe greater than that of the other nationalities in 2010-11, but not in 2004, when a more marked effect was exerted by Spanish and Italian origin (the latter with a nonsignificant statistical difference).

In sum, European citizens who move from one EU member state to another feel more European than their peers who spend their lives within the boundaries of their country of birth. ${ }^{18}$ But freedom of movement does not exhaust the opportunities for interaction across national borders created by European integration and, simultaneously, globalization. Mobility is only one of a broad set of transnational behaviours that can spill over into a stronger European identity. Eurobarometer 73 provides an opportunity to track down a large palette of transnational practices among Europeans, as it contains a series of dichotomous items on the basis of which I constructed an additive index of 'individual transnationalism'. Indicators were divided into three categories - strong, moderate, and weak $^{19}$ transnational behaviours - assigning them different weights in the index (15 per cent, 10 per cent, and 5 per cent):

\footnotetext{
${ }^{18}$ Moreover, studies focusing on migrants in Europe indicate that intra-EU migrants tend to identify more with Europe than third-country nationals, (A Roeder, 'Does Mobility Matter for Attitudes to Europe? A Multi-level Analysis of Immigrants' Attitudes to European Unification' (2011) 59 Political Studies 458; D Di Mauro and I Fiket, 'Discovering Europe? Identity of Migrants in the EU' in I Tarrósy, Á Tuka, Z Vörös and A Schmidt (eds), European Integration: Perspectives and Challenges: How 'Borderless' Is Europe? (Pécs, University of Pécs, 2014). Van Mol shows that the association between mobility experiences and European identification holds even in case of relatively short settlements, like Erasmus grants (lasting no more than 12 months), see: C Van Mol, Intra-European student mobility in international higher education circuits: Europe on the move (Basingstoke, Palgrave, 2014). Finally, even among migrants (in the German case), it is found that 'those who are spatially more mobile are those identifying the most as European', see C Teney, L Hanquinet, and K Bürkin, 'Feeling European: an exploration of ethnic disparities among immigrants' (2016) 42 Journal of Ethnic Migration Studies 2182, 2193.

19 This classification of transnational behaviours according to their intensity seems to be the best one possible given the indicators available in Eb73. In theoretical terms, I have elsewhere proposed a more composite classification which rests on a fundamental distinction between transnationalism practices which depend on physical mobility (long/brief residence abroad) and virtual mobility (personal/impersonal), see: E Recchi, 'Pathways to European Identity Formation: A Tale of Two Models' (2014) 27 Innovation: The European Journal of Social Science Research 119. Another classification distinguishes three dimensions of transnationalism relative to background, practices, and human capital, see: T Kuhn 'Individual
} 
- Had worked abroad for more than three months (15 per cent);

- Had studied abroad for more than three months (15 per cent);

- Had lived abroad for more than three months (for reasons other than work or study) (15 per cent);

- Had or had had a partner who was or had been a citizen of another country (15 per cent);

- Normally spent holidays abroad (10 per cent);

- Owned property abroad (10 per cent);

- Had family members living abroad (5 per cent);

- Had friends living abroad (5 per cent);

- Regularly followed news about another country (5 per cent);

- Regularly cooked typical dishes of another country (5 per cent).

The index of individual transnationalism thus constructed varies from 0 (no transnational experience) to 20 (involvement in all transnational practices). Its distribution in the sample is, in fact, markedly unbalanced. Only 6.6 per cent of the interviewees record scores over 10, while fully 48.1 per cent record 2 (the median) or less. The average score is 3.04. Multivariate analysis ${ }^{20}$ confirms that people in the upper class, with higher educational qualifications, younger, male, and resident in large cities, were likely to have higher scores. Moreover, not surprisingly, transnationalism was found to be more widespread among people living in the richest and most globalized countries.

Table 2. Mobility experiences, individual transnationalism and attachment to the EU in the EU population: multilevel logit regressions ('very attached' vs. 'fairly, not very or not at all attached') 


\begin{tabular}{ccc} 
Only & Past mobility & Individual \\
control & abroad & transnationalism \\
variables & $(\geq 3$ months $)$ & index \\
\hline
\end{tabular}

Individual-level variables

International mobility ( $\geq 3$ months)

\section{$1.654 * * *$}

Individual transnationalism index

Gender (=woman)

Age

Age (squared)

$\begin{array}{rr}.885 * * & .902 * \\ .986 * & .983 * \\ 1.000 & 1.000\end{array}$

Education (ref: Low, up to 15)

Middle (up to 16-19)

1.078

$1.496 * * *$

1.082

1.059

High (over 19)

Social class (ref: Inactive)

Bourgeoisie (I)
Salariat (II)
Routine white collar (III)
Petty bourgeoisie (IV)
Working class (V-VI-VII)

\section{$1.408 * *$}

.856

1.038

.855

1.063

Internet use ( 7 points scale)

$1.068 * * *$

$1.347 * * *$

Local identification

Region/county identification

1.808

$* * *$

National identification

$4.005 * * *$

Country level

variables

EU15 member state

.736

.748

.824

1.000

1.000

1.000

Gdp per capita (thousands, \$)

1.000

1.000

1.000

Unemployment rate

1.000

.998

.996

Globalization index (Kof)

1.004

1.004

1.005

Intercept

.017

.014

.013 
Log-likelihood

Wald chi-square
$-7708.84$

1184.82
$-7664.49$

1259.70
$-7561.52$

1414.60

Source: Eurobarometer 73 (2010). $\mathrm{n}=26,582, \mathrm{~N}=27$.

Note: $* \mathrm{p}<.05, * * \mathrm{p}<.01, * * * \mathrm{p}<.001$. Coefficients are odds ratios.

Table 2 sets out the results of three multilevel logistic regression models used to test the hypothesis that international mobility and transnationalism influence the sense of belonging to the EU. ${ }^{21}$ The first model does not include the independent variables of interest - that is, the experience of international mobility (having lived abroad for more than three months) and the individual transnationalism index - so as to highlight their separate explanatory power.

In general, multilevel models are used if it is believed that the parameters relative to the individual factors do not vary independently but according to patterns typical of the higher-order units - in the present case, countries. The analysis is thus able to account for a more complex variability compared with the non-hierarchical models employed previously, given the larger number of countries considered (the then 27 member states of the EU). ${ }^{22}$ It is also possible to control for a number of potentially significant context variables: in particular, the membership or otherwise of the residence country in the EU15, postulating that European identification is stronger the longer a country has been a member state of the $\mathrm{EU} ;{ }^{23}$ national demographic size, presuming that smaller states have a higher interest in European integration; ${ }^{24}$ per capita income and the unemployment rate,

\footnotetext{
${ }^{21}$ Differently from previous models, in this analysis the 'international mobility' variable is not restricted to current mobility but also includes past experiences, and it is not limited to movements within the EU but to any possible foreign country. Moreover, the sample is the EU-wide Eurobarometer, and not a casecontrol combination of two different surveys as before. All this provides an even stronger test of the mobility-supranational identity link.

${ }^{22}$ In the logistic regression models estimated previously, by contrast, the number of countries was too small to use hierarchical models, see MR Steenbergen and BS Jones, 'Modeling Multilevel Data Structures' (2002) 46 American Journal of Political Science 218, 219. Moreover, EU movers and stayers share nationality but not residence: therefore, a common dependence on the context would have been an unrealistic assumption.

${ }^{23}$ S Nissen, 'European Identity and the Future of Europe' in M Bach, C Lahusen and G Vobruba (eds), Europe in Motion: Social Dynamics and Political Institutions in an Enlarging Europe (Berlin, Sigma, 2005).

${ }^{24}$ R Steinmetz and A Wivel, Small States in Europe: Challenges and Opportunities (Farnham, Ashgate, 2010).
} 
given the greater utility deriving to economically weaker countries from EU membership; ${ }^{25}$ and the country's level of globalization (measured with the KOF index already used in the Introduction), on the assumption that societal openness to the global dimension creates a climate conducive to supranational identities. ${ }^{26}$

None of the national-level variables included in the models proves significant. To single out the conditions under which a more solid European identification develops therefore requires shifting the focus to factors operating at the individual level. The model also includes an additional variable measuring the frequency of Internet use among the interviewees. Although not a direct expression of transnationalism (the web can be used to search for local information), the fact that this variable is significantly associated with a stronger attachment to the EU seems to bear out the central hypothesis that activities spanning over national borders foster a sense of supranational identification.

This hypothesis is decidedly corroborated when the experience of (past or current) mobility abroad (model 2) and the individual transnationalism index (model 3) are introduced. The effect of each of these variables is markedly positive and significant. But that of transnationalism, including a range of practices wider than only sojourns in another country, is even stronger - when comparing the coefficients, consider that 'mobility' is a dichotomy, while the transnationalism index varies on a 20-points scale. It is also noteworthy that the model including the social transnationalism index has a better overall fit, but the significance of upper class membership and urban-metropolitan residence disappears. Moreover, once the social transnationalism index is introduced, the effect of education diminishes. It seems likely that in the first model the large part of class and education effects 'incorporated' transnationalism, which thus emerges as a more direct cause of supranational identification.

Overall, evidence presented in this section resonates with other analyses carried out in parallel with different datasets and modelling. Examining Eurobarometer data relative to support for the EU and data relative to the transnational practices of Europeans, Fligstein

\footnotetext{
${ }^{25}$ RC Eichenberg and RJ Dalton, 'Europeans and the European Union: the Dynamics of Public Support for European Integration' (1993) 47 International Organization 507; M Gabel and H Palmer, 'Understanding Variation in Public Support for European Integration' (1995) 27 European Journal of Political Research 3.

${ }^{26}$ JK Jung, 'Growing Supranational Identities in a Globalising World? A Multilevel Analysis of the World Values Surveys' (2008) 47 European Journal of Political Research 578; W Haller and V Roudometof, 'The Cosmopolitan-Local Continuum in a Cross-National Perspective' (2010) 46 Journal of Sociology 277.
} 
noted that the same social categories - young people, more highly educated individuals, and members of the upper social strata - figure among the most pro-Europe and transnational citizens. ${ }^{27}$ However, because his analysis was conducted on separate data, he was unable to prove that the two phenomena were indeed associated (i.e., that the supporters of European integration and the Europeans with the most experience of mobility were the same people). A German pioneer study found that cross-border mobility and practices go hand in hand with cosmopolitan ${ }^{28}$ identification. Interestingly, another German study indicates that the transnationalism-cosmopolitanism association is stronger among ordinary citizens than it is in the elite. ${ }^{29}$ This probably reflects a ceiling effect, as the members of the elite are homogenously highly transnational. ${ }^{30}$

The most powerful study on the transnationalism-Europeanness association is however Kuhn's. ${ }^{31}$ Her point of departure is an apparent inconsistency: at the aggregate level, transnational contacts have proliferated in Europe since the 1970s, while support for European institutions has stagnated, with some trendless fluctuations. In fact, the transnationalism-European identification association is incontrovertible at the individual level, but it does not show up in aggregate terms because it is strongly stratified. In other words, the rise in the volume of transnational activities is disproportionately due to privileged social strata, a group that also expresses strong support for the EU. Kuhn's analysis reveals that transnational practices (hinged on cross-border mobility) sustain European identification (and EU support) more than a transnational background and transnational human capital. Moreover, EU-based transnational practices affect pro-EU

\footnotetext{
${ }^{27}$ N Fligstein, Euroclash: The EU, European Identity, and the Future of Europe (Oxford, Oxford University Press, 2008).

${ }^{28}$ S Mau, J Mewes and A Zimmermann, 'Cosmopolitan Attitudes Through Transnational Social Practices?' (2008) 8 Global Networks 1.

${ }^{29}$ M Helbling and C Teney, 'The Cosmopolitan Elite in Germany: Transnationalism and Postmaterialism' (2015) 15 Global Networks 446.

${ }^{30}$ It is worth noting that, both in the general public and the elites, cosmopolitanism does not come at the expense of local identities, see: V Roudometof, 'Transnationalism, Cosmopolitanism and Glocalization' (2005) 53 Current Sociology 113; P Gustafson, 'More Cosmopolitan, No Less Local - The Orientations of International Travellers' (2009) 11 European Societies 25. Local and global identifications are not incompatible and can be nested one into the other, see: J Díez Medrano and P Gutiérrez, 'Nested Identities: National and European Identity in Spain' (2001) 24 Ethnic and Racial Studies 753; Risse (note 16). Qualitative studies of European upper-middle classes confirm the coexistence of international travels, migration experiences, and foreign friendships with a persistent focus on the issues, debates, and identities of the place of residence (M Savage et al, Globalisation and belonging (Thousand Oaks, CA: Sage, 2004); A Andreotti, P Le Galès, and FJ Moreno-Fuentes, Globalised Minds, Roots in the City: Urban Uppermiddle Classes in Europe (Oxford, Wiley \& Sons, 2014).

31 T Kuhn, Experiencing European Integration: Transnational Lives and European Identity (Oxford, Oxford University Press, 2015).
} 
attitudes more than experiences of transnationalism that are geographically anchored outside the European space. Finally, the transnationalism-EU identification association is accentuated in the most globalized European countries, where highly transnational individuals are more Europhile and 'non-transnationals' are more vigorously Euroskeptic, possibly feeling marginalized and threatened by European integration.

\section{Conclusion}

Collective politico-territorial identification is a pre-condition for the legitimacy of any political order - and all the more so of democracies. The EU has suffered from this legitimacy deficit since long. Is free movement an antidote to such inherent fragility? And what about cross-national practices that do not imply population resettlement but make nonetheless people move physically or culturally from one country to another? In the theoretical section of this chapter $(\S 1)$, I have mobilized existing literature to argue that intra-EU migration and individual transnationalism are likely predictors of enhanced identification with Europe. In the empirical section (§ 2), I have shown that mass surveys - some of which analyzed in greater detail - corroborate such theoretical expectations.

However, these findings must be placed in perspective: Intra-EU mobility and individual transnationalism remain minority phenomena and this puts a brake to their culturally integrating effects, in two senses. First, demographically individuals who have an opportunity to enlarge their 'space-sets' to a EU-wide scale are still a tiny proportion of the European population. In particular, free movement can be an engine of Europeanness, but its horsepower so far has not been sufficient to act as a locomotive of further identitarian integration. Second, ideologically: because the stratified nature of intra-EU mobility and transnational practices (involving mostly the highly educated, young and more privileged strata of the population) generates an anti-mobility reaction in the most sedentary part of the citizenry. One of Kuhn's finding mentioned above - which she appropriately terms "the Janus face" of expanding transnationalism ${ }^{32}$ - warns that a legitimacy crisis can also be triggered by unintended backlash effects of a more mobile world. Mobility can bring about a divide between an ever more globalized upper class and a comparatively localized mass resenting the lack of transnationally generated opportunities. This 'local-cosmopolitan' polarization, well known to classic American

\footnotetext{
${ }^{32}$ Kuhn (note 31) 127.
} 
sociology, ${ }^{33}$ may regain salience on a larger scale. Differences in social transnationalism lie at the roots of the politically relevant divide between 'winners and losers of globalization'. ${ }^{34}$ In attitudinal terms, these may be mirrored in the emerging 'cosmopolitanism-sovereigntism' ideological struggle that, around the theme of the permeability of nation-state borders, is supplanting the traditionalism-libertarianism dialectic in advanced societies. ${ }^{35}$

Such tension is echoed in the 'boundary work' that permeates EU politics and that migration flows - especially when they reach an extraordinary intensity, as during the asylum-seekers' crisis of 2015-2016 in Europe - magnify. Citizenship is inherently exclusive, and European citizenship makes no exception. Inflows of aliens reinforce the salience of the 'us vs. them' frame of political life in the populace, especially among those who do not share transnational practices themselves and who are the prime supporters of the "Fortress Europe" philosophy of migration policies. ${ }^{36}$ The less mobile are likely to accentuate mobility as an all-encompassing threat, ultimately willing to get away with all legal foundations to transnational behaviours - including the EU free movement regime. As the "local vs cosmopolitan" divide grows larger, reproducing the "winners vs losers of globalization" dialectic, free movement becomes an easy target for right- and left-wing nostalgics of an idealized, more protective, state-centred world.

${ }^{33}$ AW Gouldner, 'Cosmopolitans and Locals: Toward an Analysis of Latent Social Roles. I' (1957) 2 Administrative Science Quarterly 281; R Merton, Social Theory and Social Structure (Glencoe, Free Press, 1968 [1957]) 368ff.

${ }^{34} \mathrm{H}$ Kriesi et al, West European Politics in the Age of Globalization (Cambridge, Cambridge University Press, 2008).

35 A Azmanova, 'After the Left-Right (Dis)continuum: Globalization and the Remaking of Europe's Ideological Geography' (2011) 5 International Political Sociology 384.

${ }^{36}$ A Geddes, Immigration and European Integration: Beyond Fortress Europe, 2nd edn (Manchester, Manchester University Press, 2008). 